\title{
Determinant of Complete Blood Count on Long Bone Diaphysis Fractures of Lower Extremity
}

\author{
Hanny R. Indrowiyono, ${ }^{1}$ A. Djarot Noersasongko, ${ }^{2}$ Andriessanto Lengkong, ${ }^{2}$ Maximillian \\ Ch. Oley, ${ }^{3}$ Mendy J. Hatibie, ${ }^{4}$ F. L. Fredrik. G. Langi ${ }^{5}$
}

\author{
${ }^{1}$ General Surgery Resident, Departement of Surgery, Faculty of Medicine, Sam Ratulangi \\ University, Manado, Indonesia \\ ${ }^{2}$ Departement of Orthopedics, Faculty of Medicine, Sam Ratulangi University - Prof. Dr. \\ R. D. Kandou General Hospital, Manado, Indonesia \\ ${ }^{3}$ Departement of Neurosurgery, Faculty of Medicine, Sam Ratulangi University - Prof. Dr. \\ R. D. Kandou General Hospital, Manado, Indonesia \\ ${ }^{4}$ Departement of Plastic Surgery, Faculty of Medicine, Sam Ratulangi University - Prof. Dr. \\ R. D. Kandou General Hospital, Manado, Indonesia \\ ${ }^{5}$ Departement of Public Health Sciences, Faculty of Medicine, Sam Ratulangi University, \\ Manado, Indonesia \\ Email: hannyrusli24@gmail.com
}

\begin{abstract}
Abstrak: Fraktur ekstremitas bawah memiliki prevalensi yang tinggi di antara jenis fraktur lainnya akibat kecelakaan. Pemeriksaan darah lengkap berperan penting dalam proliferasi osteoblas yang merupakan langkah awal dalam penyembuhan tulang. Penelitian ini bertujuan untuk membuktikan hubungan antara penyembuhan tulang dengan determinan darah lengkap dan hubungan determinan darah lengkap dengan jenis fraktur, lokasi fraktur, faktor-faktor demografik, dan parameter darah tepi pada pasien fraktur diafisis tulang panjang ekstremitas bawah. Penelitian ini dilaksanakan di RSUP Prof. Dr. R. D. Kandou, Manado menggunakan studi kohort (analitik observasional) dengan 10 pasien fraktur terbuka (grade I-II) dan 14 pasien fraktur tertutup. Semua pasien dilakukan pemeriksaan fisik dan pemeriksaan laboratorium darah lengkap. Hasil penelitian mendapatkan pasien laki-laki lebih banyak dibanding perempuan, median usia 30 tahun. Hasil analisis regresi mendapatkan perbedaan hasil darah lengkap pada fraktur terbuka dan fraktur tertutup (leukosit dan neutrofil batang) dan hasil bermakna pada perbedaan lokasi fraktur di femur dan tibia. Simpulan penelitian ini ialah penderita fraktur diafisis ekstremitas bawah terbuka memiliki infeksi lebih tinggi dengan ditandai peningkatan leukosit dan neutrofil batang
\end{abstract}

Kata kunci: kadar darah lengkap; fraktur diafisis; tulang panjang

\begin{abstract}
Lower limb fracture has a high prevalence among other types of fractures due to accidents. Complete blood count has an important role in the proliferation of osteoblasts which is the first step in bone healing. This study was aimed to prove the relationship between bone healing and determinants of complete blood count and to prove the relationship between determinants of complete blood count and fracture type, fracture location, demographic factors, and peripheral blood parameters in patients with diaphysis fractures of the long bones of lower extremities. This study was conducted at Prof. Dr. R. D. Kandou Hospital, Manado using a cohort study (observational and analytical) with 10 open fracture patients (grade I-II) and 14 closed fracture patients. All patients were subjected to physical examination and complete blood count laboratory. The results showed that male subjects were predominant and the median age was 30 years. The regression analysis showed that there were differences in complete blood count between open fractures and closed fractures (leukocytes and band neutrophil) and significant differences in the location of fractures in the femur and tibia. In conclusion, leukocyte and segmented neutrophils levels are increased in patients with open lower limb diaphysis fractures
\end{abstract}

Keywords: complete blood count; long bone; diaphysis fracture 


\section{INTRODUCTION}

More than 5.6 million people died and around 1.3 million people had physical disabilities due to accidents according to WHO. Lower limb fractures had one of the highest prevalence on accidents, which occur to $\sim 40 \%$ of the accidents. ${ }^{1}$

Bone healing is a complex physiological and metabolic process in fractured bones involving a wide variety of biochemical, cellular, hormonal and pathological mechanisms. ${ }^{2}$ The bone healing process includes the hematoma phase, the inflammatory and cellular proliferation phase, the callus formation phase, the consolidation phase and the remodeling phase. In the inflammatory phase, it starts because the role of cytokines, namely interleukin (IL-1, IL-6) and tumor necrosis factor- $\alpha$ (TNF- $\alpha$ ) resulting from macrophage cells and mesenchymal cells. ${ }^{15}$ However, during the initial phase of bone healing, the condition around the fracture is hypoxic. Hypoxic environment triggers some signals for angiogenesis and other healing factors. ${ }^{3-5}$ This study was aimed to prove the relationship between bone healing and serum complete blood count (count complete types, blood sugar, liver and kidney function, and electrolytes) and the type of fracture, fracture location, demographic factors (age and sex) in patients with long bone shaft fractures in lower limb. ${ }^{6-8}$

\section{METHODS}

This study was conducted at Prof. Dr. R. D. Kandou General Hospital Manado from March 2020 to August 2020. This was an observational study using a cross-sectional design. Data were collected prospectively consisting of every patients' data who met the study criterias. Samples were not collected by the status of exposure and data sampling was done once without follow-up. Subjects of this study were patients who met all the criteria, as follows: patients with diaphysis fractures of the lower extremity; ages 18-40 years; and had given written consent to participate in the study through the Informed Consent sheet. Those who met the inclusion criteria then were excluded from the samples if known to have any of these: uncontrolled diabetes, malignancy, coagulopathy, or peripheral vascular disease.

The main instrument of this study was the analysis of the patients' blood serum which had received treatment for long bone shaft fractures of the lower limb. Blood were taken from peripheral vein on the 5th day after the accident. Blood samples were stored at $2-5^{\circ} \mathrm{C}$, before centrifugation $(1000$ revolutions/minute) for 60 minutes until coagulation occurred, then the results were stored at $-80^{\circ} \mathrm{C}$ until the time for analysis.

Descriptive analysis was carried out by using univariate and bivariate analyses. The bivariate relationship between the type and location of the fracture and complete blood count were evaluated by using the t-test. The determinant of complete blood count was determined by linear regression analysis.

Most of the data management used the statistical software application version $\mathrm{R}$ version 4.0.2, which is also the main tool for statistical analysis. This study has received approval from the Health Research Ethics Commission of Prof. Dr. R. D. Kandou Manado No. 050/EC/KEPK-KANDOU/ VII/2020.

\section{RESULTS}

This study managed to collect data of 24 patients with long bone shaft fractures of the lower limb. Ten patients (42\%) had open fractures; all of them were male. The demographic, clinical, and laboratory characteristics of the patients were shown in Table 1 . The median age of all patients was 30 years. Male sex dominated the study samples with a ratio of up to 9: 1 to female sex. Overall, the proportion of femur diaphysis fractures was lower than that of the tibia/fibula $(46 \%$ vs $54 \%)$. It also showed that more closed fracture occurred in the femur diaphysis $(p=0.005)$. The patient's hemoglobin level was relatively within normal limits with no significant difference between the two types of fractures. They had an average of leukocytosis, where the mean value of open fracture cases was significantly higher than that of the closed ones $(16,200 / \mu \mathrm{L}$ vs. $13,600 / \mu \mathrm{L}$; 
$\mathrm{p}=0.031$ ). In the parameter count, the percentage of neutrophils band in open fracture patients was also higher than in closed fracture patients. Serum sodium levels tended to be near the lower limit of the normal value of $135 \mathrm{mmol} / \mathrm{L}$. Other blood examination results were relatively within normal limits without any indication of differences in values between the two types of fracture cases. However, thrombocytes (platelets) in open fracture patients showed greater value than in closed fracture patients
$(234,000 / \mu 1$ vs $210,000 / \mu 1 ; p=0.682)$.

\section{DISCUSSION}

This study showed that the open fracture patients had a median age of 13 years older than the closed fracture patients. Male sex dominated the study samples with a ratio of up to 9:1 to female sex.

Overall, the proportion of fractures in the femoral diaphysis was lower than that of the tibia/fibula (46\% vs $54 \%$ ).

Table 1. Characteristics of patients

\begin{tabular}{|c|c|c|c|c|c|c|c|}
\hline \multirow{3}{*}{ Characteristics } & \multicolumn{6}{|c|}{ Fracture Type } & \multirow[b]{3}{*}{$p$} \\
\hline & \multicolumn{2}{|c|}{ Total $\left(N=24^{\mathrm{a}}\right)$} & \multicolumn{2}{|c|}{ Open $(n=10)$} & \multicolumn{2}{|c|}{ Close $(n=14)$} & \\
\hline & $\begin{array}{c}n(\%), \text { or } \\
\text { Mean (SD) }\end{array}$ & $\begin{array}{c}\text { Median } \\
(Q 1-Q 3) \\
\end{array}$ & $\begin{array}{c}n(\%), \text { or } \\
\text { Mean (SD) }\end{array}$ & $\begin{array}{c}\text { Median } \\
(Q 1-Q 3) \\
\end{array}$ & $\begin{array}{c}n(\%), \text { or } \\
\text { Mean (SD) }\end{array}$ & $\begin{array}{c}\text { Median } \\
(Q 1-Q 3) \\
\end{array}$ & \\
\hline Age & $*$ & $29.5(20.8-38.0)$ & $*$ & $37.0(28.8-39.0)$ & $*$ & $23.5(19.2-32.8)$ & 0.073 \\
\hline \multicolumn{8}{|l|}{ Gender, $n(\%)$} \\
\hline Male & $21(88)$ & $*$ & $10(100)$ & $*$ & $11(79)$ & $*$ & 0.239 \\
\hline Female & $3(12)$ & $*$ & $0(0)$ & $*$ & $3(21)$ & $*$ & \\
\hline \multicolumn{8}{|l|}{ Fracture Location, $n(\%)$} \\
\hline Femur & $11(46)$ & $*$ & $1(10)$ & $*$ & $10(71)$ & $*$ & 0.005 \\
\hline Tibia/Fibula & $13(54)$ & $*$ & $9(90)$ & $*$ & $4(29)$ & $*$ & \\
\hline Hemoglobin (g/dL) & $12.5(1.7)$ & $*$ & $12.9(2.0)$ & $*$ & $12.2(1.4)$ & $*$ & 0.294 \\
\hline Hematocrit (\%) & $36.6(4.8)$ & $*$ & $37.5(5.7)$ & $*$ & $36.0(4.2)$ & $*$ & 0.474 \\
\hline Erythrocytes $\left(\times 10^{6} / \mu \mathrm{L}\right)$ & $4.1(0.7)$ & $*$ & $4.4(0.9)$ & $*$ & $3.9(0.5)$ & $*$ & 0.086 \\
\hline Platelets $\left(\times 10^{3} / \mu \mathrm{L}\right)$ & $*$ & $223,5(180,2-267,5)$ & $*$ & $234,0(180,5-260,0)$ & $*$ & $210,0(181,2-272,0)$ & 0.682 \\
\hline Leukocytes $\left(\times 10^{3} / \mu \mathrm{L}\right)$ & $14.7(3.0)$ & $*$ & $16.2(3.1)$ & $*$ & $13.6(2.6)$ & $*$ & 0.031 \\
\hline Eosinophlis (\%) & $*$ & $0.0(0.0-1.5)$ & $*$ & $0.0(0.0-0.0)$ & $*$ & $1.0(0.0-3.0)$ & 0.124 \\
\hline Neutrophil-Band (\%) & $*$ & $2.0(0.0-3.5)$ & $*$ & $5.0(4.0-10.5)$ & $*$ & $0.0(0.0-2.0)$ & 0.021 \\
\hline Neutrophil-Segmented (\%) & $70.8(10.0)$ & $*$ & $72.3(9.3)$ & $*$ & $69.8(11.4)$ & $*$ & 0.758 \\
\hline Lymphocytes (\%) & $16.8(8.9)$ & $*$ & $13.0(6.2)$ & $*$ & $19.0(10.2)$ & $*$ & 0.399 \\
\hline Monocytes (\%) & $7.6(1.3)$ & $*$ & $6.7(0.6)$ & $*$ & $8.2(1.3)$ & $*$ & 0.109 \\
\hline Blood Glucose (mg/dL) & $*$ & $93.5(86.8-108.8)$ & $*$ & $103.0(89.0-107.5)$ & $*$ & $92.5(84.5-109.2)$ & 0.660 \\
\hline $\operatorname{AST}(\mathrm{U} / \mathrm{L})$ & $*$ & $29.0(22.0-37.2)$ & $*$ & $30.0(23.0-36.8)$ & $*$ & $28.5(22.5-41.0)$ & 0.837 \\
\hline ALT (U/L) & $*$ & $18.5(13.0-30.2)$ & $*$ & $13.5(13.0-22.8)$ & $*$ & $22.5(13.2-32.8)$ & 0.557 \\
\hline Urea (mg/dL) & $*$ & $27.0(23.8-38.8)$ & $*$ & $27.0(24.0-31.0)$ & $*$ & $29.0(23.3-41.0)$ & 0.814 \\
\hline Creatinine (mg/dL) & $0.9(0.3)$ & $*$ & $0.9(0.3)$ & $*$ & $0.9(0.3)$ & $*$ & 0.857 \\
\hline Sodium (mmol/L) & $134.1(4.3)$ & $*$ & $134.5(4.2)$ & $*$ & $133.9(4.4)$ & $*$ & 0.725 \\
\hline Potassium (mmol/L) & $*$ & $3.9(3.0-4.1)$ & $*$ & $3.3(3.0-3.9)$ & $*$ & $4.0(3.1-4.1)$ & 0.598 \\
\hline Chloride (mmol/L) & $*$ & $98.0(96.2-98.7)$ & $*$ & $98.8(97.4-99.9)$ & $*$ & $97.4(96.2-98.3)$ & 0.089 \\
\hline
\end{tabular}

NOTE: SD standard deviation, Q1 quartile 1. Q3 quartile III. POSAS patient and observer scar assessment scales. the Twenty subjects each received the two techniques simultaneously, this explains a total of 40 . $b$ The results of the paired t test or the Wilcoxon rank sum test on numeric variables. Friedman's $x^{2}$ test on categorical variables. 
It also showed that more closed fracture occurred in the femur diaphysis $(\mathrm{p}=0.005)$. Other studies show that older age has a higher incidence of open fracture because of the aging process of the skin due to decreasing collagen deposits thus causing easier open fractures to occur when there is a trauma, even with a tiny energy force beside some other affecting factors such as the mechanism of injury and the amount of energy released. ${ }^{9}$

Among all repair processes within the body, fracture healing is characterized by internal remodelling of the original tissue without formation of scar tissue. Fracture healing is a complicated process; the durability, formation, reproduction, and structuring of which involve many general and local regulators. This process consists of hematoma, inflammation, soft callus, hard callus, and remodelling stages, but still there are many points that need to be exposed. ${ }^{5}$

This study showed that thrombocytes tended to increase higher in open fracture patients than in closed fracture patients. The role of thrombocytes in wound healing has been underlined many times previously. ${ }^{6}$ Thrombocytes release many growth factors, which play a role in thrombus formation and wound healing, in addition to mediators such as thromboxane A2 and prostaglandin, which are important in both wound healing and bone remodelling. Their effects on bone may be seen during acute (fracture) and chronic (osteoporosis) conditions. ${ }^{7}$ Supporting effects of thrombocytes on bone formation have been reported in both in vitro and clinical studies. ${ }^{6}$ Thrombocytes promote bone regeneration by accelerating migration and proliferation of osteogenic cells, increasing blood vessel formation, and inducing inflammatory reaction. ${ }^{8}$ Thrombocyte-derived growth factors promote bone formation by affecting cell proliferation, chemotaxis, differentiation, and synthesis of extracellular matrix. ${ }^{9}$ Additionally, their protective effect on bone has been demonstrated in clinical studies. Nevins et $\mathrm{al}^{12}$ reported that platelet-rich plasma (PRP) has high amounts of growth factors, and it is positively associated with bone formation. Unfortunately, studies demonstrating in- creased bone formation by PRP via activation of osteoblasts have remained limited to dental clinical studies and in vitro studies. Ogino et $\mathrm{al}^{13}$ demonstrated inhibitory effects of PRP on osteoclast-like cell formation in the bone marrow. Another study by Ogino et al evaluated the effects of PRP on the release of osteoprotegerin (OPG) from the bone marrow cells of rats and found that PRP had a stimulating effect on OPG in the absence of vitamin D3. Recent advances in clinical laboratory methods have opened new avenues for the understanding of platelets' role in thrombosis, immunity, inflammation, and angiogenesis. ${ }^{13}$ One of the most important effects of thrombocytes is including a series of substances affecting proinflammatory process. These substances are accepted as mediators of inflammatory cells. Thrombocytes are generally classified within blood cells and undoubtedly play important roles in hemostasis and thrombosis. Stored thrombocytes play important role in acute inflammatory response and may show direct antimicrobial activity such as neutrophil, granulocyte, and monocyte. ${ }^{14}$

Results showed that leucocyte and segmented neutrophil values had higher values in open diaphysis fractures. This is due to the contamination and infection processes that occur in open fractures are more intense than in closed fractures. ${ }^{15}$

With high levels of segmented leukocytes and neutrophils, it will cause a higher inflammatory reaction thus inhibiting the proliferation process. The inflammatory phase arises because of the role of interleukin cytokines (IL-1, IL-6) and tumor necrosis factor- $\alpha$ (TNF- $\alpha$ ) produced from macrophage cells. High inflammatory reactions will trigger inhibition of the proliferation process, which is a signal for angiogenesis and healing factors. ${ }^{15}$

Based on the study of Morell et $\mathrm{al}^{3}$ leukocytosis had been correlated with the severity of trauma patients as well as of their length of stay in the intensive care unit. $^{3}$ Neutrophilia in this series is a reactive phenomenon that may associated with inflammation. Most of this process occurs as 
a reaction to some inflammatory processes, and other causes may include physiological stress, medication or drugs, and tissue necrosis. ${ }^{4}$

\section{CONCLUSION}

Patients with open lower limb diaphysis fractures have higher infection with marked increases in leukocytes and segmented neutrophils. Thrombocytes have a role on bone healing but need further research to prove the role on bone healing.

\section{Conflict of Interest}

The author states that there is no conflict of interest in this study.

\section{REFERENCES}

1. Schlickewei CW, Kleinertz H, Thiesen DM, Mader K, Priemel M, Frosch K-H, et al. Current and future concepts for the treatment of impaired fracture healing. Int J Mol Sci [Internet]. 2019;20(22): 5805. Available from: https://www. mdpi.com/1422-0067/20/22/5805\%0A http://www.ncbi.nlm.nih.gov/pubmed/3 1752267

2. Marongiu G, Dolci A, Verona M, Capone A. The biology and treatment of acute longbones diaphyseal fractures: overview of the current options for bone healing enhancement. Bone reports [Internet]. 2020;12(January):100249. Available from: https://doi.org/10.1016/j.bonr. 2020.100249

3. Morell V, Lundgren E, Gillott A. Predicting severity of trauma by admission white blood cell count, serum potassium level, and arterial pH. South Med J. 1993; 86:658-9.

4. Haug RH, Reifeis RL. A prospective evaluation of the value of preoperative laboratory testing for office anesthesia and sedation. J Oral Maxillofac Surg. 1999;57: $16 \mathrm{Y} 20$.

5. Termaat MF, Den Boer FC, Bakker FC, Patka $\mathrm{P}$, Haarman HJ. Bone morphogenetic proteins. Development and clinical efficacy in the treatment of fractures and bone defects. J Bone Joint Surg Am. 2005;87(6):1367-78.

6. Gruber R, Varga F, Fischer MB, Watzek G.
Platelets stimulate proliferation of bone cells: involvement of platelet-derived growth factor, microparticles and membranes. Clin Oral Implants Res. 2002;13(5):529-35.

7. Sharif PS, Abdollahi M. The role of platelets in bone remodeling. Inflamm Allergy Drug Targets. 2010;9(5):393-9.

8. Hofman M, Koopmans G, Kobbe P, Poeze M, Andruzkow H, Brink PRG, et al. Improved fracture healing in patients with concomitant traumatic brain injury: proven or not? Mediators Inflamm. 2015;2015:204842.

9. Jiang D, Dziak R, Lynch SE, Stephan EB. Modification of an osteoconductive anorganic bovine bone mineral matrix with growth factors. J Periodontol. 1999;70(8):834-9.

10. Court-Brown CM, Biant LC, Clement ND, Bugler KE, Duckworth AD, McQueen MM. Open fractures in the elderly. The importance of skin ageing. Injury [Internet]. 2015;46(2):189-94. Available from: http://dx.doi.org/10.1016/ j.injury.2014.07.021

11. Huh JH, Choi SI, Lim JS, Chung CH, Shin JY, Lee MY. Lower serum creatinine is associated with low bone mineral density in subjects without overt nephropathy. PLoS One. 2015;10(7):1-11.

12. Nevins M, Camelo M, Nevins ML, Schenk RK, Lynch SE. Periodontal regeneration in humans using recombinant human platelet-derived growth factor-BB (rhPDGF-BB) and allogenic bone. J Periodontol. 2003;74(9):1282-92.

13. Ogino Y, Ayukawa Y, Kukita T, Atsuta I, Koyano K. Platelet-rich plasma suppresses osteoclastogenesis by promoting the secretion of osteoprotegerin. J Periodontal Res. 2009;44(2):217-24.

14. Smyth SS, McEver RP, Weyrich AS, et al. Platelet colloquium participants. Platelet functions beyond hemostasis. J Thromb Haemost. 2009;7(11):1759-66.

15. Folkman J, Brem H. Angiogenesis and inflammation. In: Gallin J, Goldstein I, Snyderman R, eds. Inflammation: Basic Principles and Clinical Correlates (2nd ed). New York: Raven Press, 1992; p. 821-39. 